\title{
PARODY AS EVALUATION: ABOUT A TELEVISION SKETCH IN SPANISH $^{1}$
}

\author{
LEONOR RUIZ GURILLO \\ University of Alicante \\ Leonor.Ruiz@ua.es
}

\begin{abstract}
Resumen
En este artículo se analiza un sketch televisivo, procedente del programa Saturday Night Live español. El sketch es un tipo de parodia muy relacionada con la sátira (Simpson, 2003:123). Como texto humorístico, se observan los rasgos de la sátira y de la parodia como tal. El repaso a la bibliografía sobre humor y en especial de la General Theory of Verbal Humor -GTVH- (Attardo, 2001a y 2008) permite contemplar las diversas fuentes de conocimiento propuestas desde la situación de la parodia y determinar que es el blanco de la burla la más importante. La discusión teórica se completa con el examen de diversas teorías sobre la sátira y la parodia, como las de Rossen-Knill \& Henry, 1997; Pueo, 2002; Simpson, 2003. Todo ello conduce a la idea de que en la parodia el elemento primordial es el acto cómico. Para lograrlo, el hablante o escritor emplea diversos elementos evaluativos. Así, en primer lugar, se examina la evaluación como parte de la narración (Labov y Waletzky, 1967). Ahora bien, dicha concepción de evaluación ha de ser completada necesariamente con la que la entiende como procedimiento (Kotthoff, 2003; Partington, 2007 y 2011). En este caso, tanto las marcas (elementos kinésicos, sonrisa,...) como los indicadores del humor (fraseología, polisemia, pseudoabarcadores,...) son elementos evaluativos.
\end{abstract}

\begin{abstract}
This article has as its aim to analyze a TV sketch from the Spanish Saturday Night Live show. The sketch is a type of parody very closely related to satire (Simpson, 2003:123). As a humorous text, it shows the features characterizing both satire and parody. A review of the bibliography on humor and especially of the General Theory of Verbal Humor - GTVH- (Attardo, 2001a and 2008) permits to study the different knowledge resources proposed from the parody situation and determine which target is the most important. The theoretical discussion is completed with the examination of several theories about satire and parody, such as those of RossenKnill \& Henry, 1997; Pueo, 2002; or Simpson, 2003. All of this leads to the idea that the comic act is the essential element in parody. The speaker or writer uses a variety of evaluative elements in order to achieve it. Thus, evaluation is firstly analyzed as a part of the narration (Labov \& Waletzky 1967). However, that evaluation concept must necessarily be completed with the one which understands evaluation as a procedure (Kotthoff, 2003; Partington, 2007 and 2011). In this case, both the markers (kinesic elements, smile,...) and indicators of humor (phraseology, polysemy, pseudocomprehensive elements,...) are evaluative elements.
\end{abstract}

\footnotetext{
${ }^{1}$ This research was supported by the Spanish Ministry of Economy and Competitiveness through the grant FFI2012-30941 "Innovaciones lingüísticas del humor: géneros textuales, identidad y enseñanza del español [Linguistic innovations of humor: textual genres, identity and Spanish learning]. For further information visit http://dfelg.ua.es/griale/ and http://humoria.blogspot.com
} 
PALABRAS CLAVE: parodia, sketch, sátira, humor, blanco de la burla.
KEY WORDS: parody, sketch, satire, humor, target.

\section{Introduction}

This article presents the analysis of parody as a form of humor. More precisely, the analysis focuses on a television sketch from the Spanish Saturday Night Live show. The sketch is a type of parody and this, in turn, "is undeniably the closest form of verbal humour to satire" (Simpson, 2003: 123). For Méndez (2004), parody is a humor category based on intertextuality, since it dialectically opposes an original text to the one built as a parody. It has an ideological component and, as far as television is concerned, it implies a frivolous use of information.

The treatment of this sketch permits to make some reflections on the relationships between humor, satire and parody. Thus, $\$ 2$ shows the pragmatic model for humor developed by the General Theory of Verbal Humor (hereinafter, GTVH) of V. Raskin and S. Attardo. The consideration of parody as a humorous text entails the development of various approaches to its specific features in $\$ 3$. $\$ 4$ contains an analysis of the evaluative aspects that surround parody, understood both as a structural part of the story and as a procedure which makes it possible to persuade the audience. Once these aspects have been settled, they are applied to analyze one of the sketches from the Saturday Night Live show in $\$ 5$. The video, which is available from Youtube, has been transcribed following the keys of the Val.Es.Co Research Group 2 . It lasts 3 minutes and 15 seconds. Finally, the article ends with some conclusions that permit to consolidate an analytical model which can be exported to other examples of parody (\$6).

\section{A pragmatic model for verbal humor}

During the last few years, the GRIALE research group has developed an analysis of irony and humor from the linguistic point of view and, more precisely, from a pragmatic perspective. Our specific model (see especially Ruiz-Gurillo, 2010 and 2012) is supported on the inferential processes which permit to understand humor and focuses on performing the following tasks:

-It tries to show generalizations in the utilization of humor.

\footnotetext{
${ }^{2}$ These transcription keys can be found in www.valesco.es.
} 
-It seeks to observe every side of the communicative phenomenon: the selected genre; the predominant text (or sequence); the context where the said humorous genre is used; to whom the mockery is addressed; which scripts are opposed in incongruity and how that incongruity is resolved; which logical mechanisms contribute to resolve it; and which mutual relationships exist between those logical mechanisms and the linguistic and paralinguistic choices carried out by the speakers/writers.

-It analyzes markers and indicators as footprints of the conscious or unconscious choices made by speakers when they use language.

Based on these premises, humor presents a set of generalizations that can be studied, which in turns makes it possible to teach or learn the aspects surrounding the utilization of this pragmatic awareness (Ruiz-Gurillo, 2006) ${ }^{3}$. The examination of the different existing theories about the pragmatic explanation of humor has led us to adopt the GTVH as the most suitable model to achieve these aims, as will be shown below.

In 1985, V. Raskin proposed his Script-based Semantic Theory of Humor (hereinafter, SSTH), which, as its name indicates, is based on the notion of script. Such a cognitive construction, also known as frame or schema by other authors, implies a structured information area which the speaker internalizes and which represents the knowledge owned by that speaker about a part of the world (Raskin, 1985: 81). The theory was improved with the arrival of Salvatore Attardo, after which they both (Attardo \& Raskin, 1991) proposed the General Theory of Verbal Humor) (hereinafter, GTVH).

Following this proposal, S. Attardo carried out a linguistic analysis of verbal humor in 1994. That analysis collects the achievements of such disciplines as semiotics or psychology. In 2001 (Attardo, 2001a), he devised a GTVH that could be applied to texts from diverse registers, to different situations (mass media) and to a variety of historical periods. The analysis consequently deals with texts which are longer than jokes, such as novels, short stories, television sitcoms, movies or games. Amongst others, it takes into

\footnotetext{
${ }^{6}$ Following Jef Verschueren's position, a conception of pragmatics as a perspective is defended. Pragmatics is therefore a cognitive, social and cultural science of language and communication which refers to the utilization of language. Using language implies making a continuous linguistic choice where three key concepts are involved, namely: variability, which determines the range of possible choices; negotiability, through which these choices can be carried out in accordance with flexible principles and strategies; and adaptability; which makes it easier for human beings to make linguistic choices that can be negotiated from a range of variable options, seeking to satisfy the communicative needs (Verschueren, 2002: 129-130 and 2009). These choices can be totally automatic or fully conscious; they all form part of language use.
} 
account criteria like the linear nature of the text, the importance of beginnings and ends of humorous structures, the roles of humor in the narration, or the humorous plot.

The SSTH is a semantic theory; the GTVH is a broader linguistic theory. Unlike the former, the GTVH is supported on six knowledge resources, which are initially applied to jokes and show a hierarchical relationship with one another (Attardo, 2001a: 22-27 and 2008: 108). These six resources, which are listed below, will determine whether any given text can be described as humorous or not:

1. Script Opposition, the basis of the SSTH and of any humorous text.

2. Logical Mechanism, which corresponds to the resolution phase in incongruityresolution models. It is the mechanism whereby the incongruity of Script Opposition is playfully and/or partially explained away. ${ }^{4}$. Different types of logical mechanisms exist, among them juxtaposition, false analogy or chiasmus.

3. Situation, essential to understand humorous texts and their inferences.

4. Target or what is known as 'butt' of the joke or humorous text. Group or individual stereotypes belong here. However, this knowledge resource may be optional because some forms of humor do not have as their aim to ridicule anyone in particular.

5. Narrative Strategy, i.e. the genre of the joke or the humorous text.

6. Language, that is, choices related to lexis, syntax, phonology, etc.

Therefore, the knowledge resources used by the humorous text are hierarchically organized as we have briefly described in Figure 1 following Attardo (2008: 28):

\footnotetext{
${ }^{4}$ The formulation for the logical mechanism presented by Attardo (2008: 108) has been chosen here. This formulation is much clearer than the one which appeared in Attardo (2001a: 25-26), where he additionally recognizes that it is the most problematic of the six parameters which form the knowledge resources for humorous texts.
} 


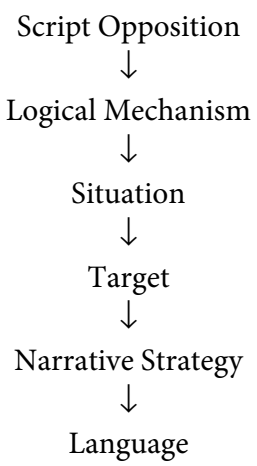

Figure 1: Hierarchical organization of knowledge resources for humorous texts according to the GTVH

This model works very well in short texts, like jokes, but it has also proved effective in longer texts. In this respect, the application of the GTVH to fragments longer than jokes offers at least four assumptions (Attardo, 2001a: 206 and 2008: 110):

1. The analysis of texts as a vector, where each humorous utterance can be coded and analyzed according to the GTVH proposal, which takes into account aspects such as script opposition, the logical mechanisms which are implemented for the resolution of incongruity or the language used.

2. The distinction between jab lines and punch lines ${ }^{5}$, the latter being the climaxes with which the humorous text is closed; jab lines may appear anywhere in the text and are completely integrated into the narrative where they appear.

3. As a consequence of it, the importance accorded to the relative distribution of the lines in the text.

4. A taxonomy and analysis of humorous plots, where the following types are distinguished:

4.1. Humorous plot with a punch line, the maximum exponent of which is the joke;

\footnotetext{
${ }^{5}$ Using the boxing metaphor, S. Attardo puts on a level the jab lines and punch lines procedures with the types of basic blows: the jab is a fast, direct blow, launched with the front hand from the on-guard position, and is understood as the most important blow available to a boxer, as it provides him with a sufficient amount of his own guard capacity and leaves very few chances for him to be punched by the opponent (Source: http://es.wikipedia.org/wiki/Boxeo; consulted on: August 4th, 2010). The punch is regarded as a final blow within this analogy, in this case of the joke or any other humorous text.
} 
4.2. Humorous plot with a metanarrative disruption; a text including one or more interruptions of the narrative conventions typical of this genre; these interruptions have a humorous nature;

4.3. Humorous plot with a humorous central complication: these are essentially texts where the central complication of the story is humorous in itself. Attardo (2008:112-113) sees it as the most interesting category among humorous plots, but also as the most problematic one.

This proposal has proved its validity over time, due to which both the SSTH of V. Raskin and the GTVH of V. Raskin and S. Attardo have become "the two most influential linguistic humor theories of the last two decades" (Brône, Feyaerts \& Veale, 2006: 203). It is therefore a widely accepted theory in linguistic research studies. In our opinion, this is due to the fact that the proposal is more far-reaching than others, since it permits to observe generalizations in the logical mechanisms used by humor in its various expressions, it understands narrative strategies as an inherent characteristic of humor, and does not forget the importance of lexical, grammatical or phonological choices. It also assigns an outstanding role to the communicative situation where the humorous text develops as well as to the addressee of the mockery. These six aspects consequently offer an integrated explanation of the communicative event represented by the humorous text, whether it is a joke, a monologue or a parody $y^{6}$.

Of these six knowledge resources, target appears as the most outstanding one in the case of parody because mockery represents one of the comic act foundations (RossenKnill \& Henry, 1997, see below). In turn, the knowledge resource identified as target organizes different humor procedures such as the provision of evaluative elements which make it easier to achieve the effects sought by the text; for instance, social or political criticism and persuasion.

\section{Satire, parody, sketch}

According to Pueo (2002), parody has become widespread in the current postmodern times; in other words, nearly everything can be parodied. For Méndez (2004), parody is a humor category based on intertextuality. Therefore, it is built on enunciative procedures, as opposed to other expressions of humor which are constructed using linguistic procedures. In this respect, Charaudeau (2006:32) pointed out that two recip-

${ }^{6}$ About a revised model for humorous texts, according to GRIALE Research Group, see Ruiz-Gurillo (2012) and Ruiz-Gurillo (2013). 
rocally-feeding texts coexist in parody: the original text is the reference; the parodic text finds its foundation in the mockery based on the original.

Following Simpson's approach (2003: 123), it is advisable to examine parody relating it to its closest form: satire. In this sense, satire is defined as a discursive practice frequently integrated into the different everyday humor practices. As such, it comprises several elements:

- The satirist, or producer of the text

- The satiree, i.e. the addressee, whether it is the reader or the listener

- The satirized, i.e. the target attacked or criticized in the satirical discourse

With regard to its linguistic properties, it works as a higher-rank discourse, since it uses a primary genre with which it establishes a dialectical relationship ${ }^{7}$. In this way, it activates a previous real or possible discursive event which becomes an echoic discourse of the satirical text. It is the dissonance between the original domain and the dialectical one that creates a pragmatic framework for interpretation. Furthermore, as Lefort (1999) equally warns us, satire fulfills an ideological role. It is the case of television parody, understood as a "critical and social response to the serious, legitimized discourses transmitted by the mass media through the traditional news programs" (Méndez, 2004: 186). More precisely, it contains:

(...) a kind of humor based on totally different contents linked to the current news in the media, which turns it into a type of discourse that does not exclusively seek laughter as a response by the viewer but a deeper effect which tries to provoke reflexive reactions that make the viewer adopt a critical stance and evaluate the topics which are the object of humor (Méndez, 2004: 163).

According to Méndez (2004 and 2009), the expressions of humor on Spanish television have evolved: there was a time when they were not autonomous, as they appeared integrated into other programs. Furthermore, they occupied much less time within the program grid. An increase of humor in television program grids with the aim of attracting the audience is detected halfway through the 1990s, coinciding with the consolidation of private channels. In this context, there was an increase of TV sitcoms, both selfproduced and foreign ones, cartoons for grown-ups, humorous monologues (La noche de la comedia [The comedy night], El club de la comedia [The comedy club]), special humor programs made by acclaimed comedians like Los Morancos or Cruz y Raya), or news programs and magazines. All of this has led to the creation of new formats, "to-

\footnotetext{
${ }^{7}$ This is why Simpson (2003: 215) does not see parody as a discursive genre strictly speaking.
} 
tally new and original discursive subgenres in the Spanish television panorama" (Méndez, 2004: 158). In fact, even some supposedly serious contents, such as the news or sports, are suffering a ludic frivolization. In this context, Méndez analyzes the magazine Caiga quien caiga [Whoever may fall] during its early stage, when it was directed by the comedian known as "el Gran Wyoming." This sort of media humor is defined as informative parody.

Summing up, parody can be said to represent a humorous discursive practice close to satire. In recent times, parody has become a highly frequent discursive exercise in television programs, which is why television or informative parody can actually be described as a specific expression of humor. These developments are illustrated by means of Figure 2:

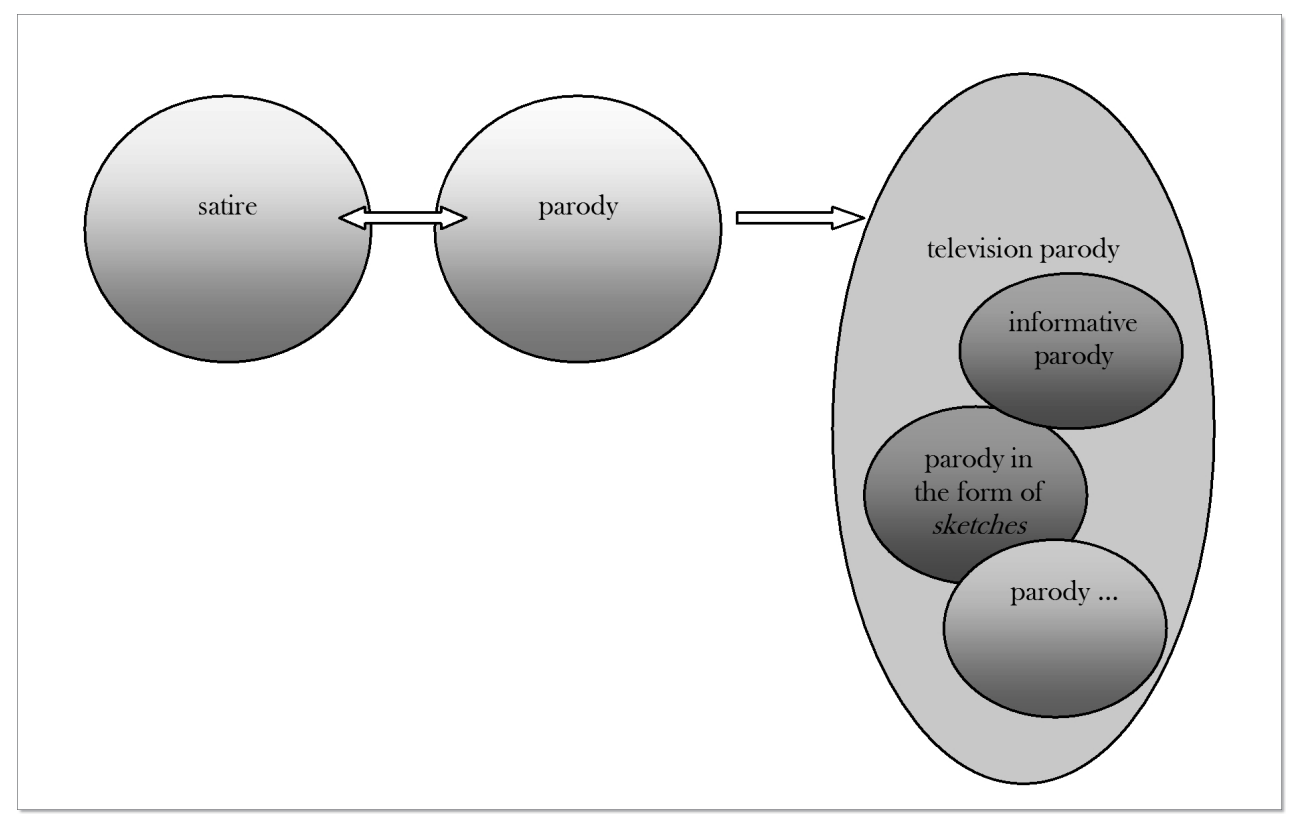

Figure 2: Relationships between satire and parody and the (possible) types of television parody

Assuming that satire and parody share their basic features, Rossen-Knill \& Henry (1997) argue that verbal parody is a speech act, as defined by J. Searle, and propose four essential features identifying it:

1. The intentional verbal representation of the object of parody, which includes a linguistic form and a target (events, actions, beliefs and thoughts...). 
2. The flaunting of the verbal representation, according to which the speaker tries to remind or bring the previous act or event that is being parodied to the listeners' memory with its representation and, secondly, tries to help listeners recognize it. It is achieved at least with laughter and with the infringement of pragmatic maxims or principles ${ }^{8}$.

3. The critical act, which ridicules the object of parody. Both the intentional representation and the flaunting carried out by the speaker remind the listener of the event which is being ridiculed. Therefore, there may be simply a joke about something or contempt may be shown in relation to the object of criticism.

4. The comic act, the final essential act of verbal parody. Seeking to achieve 'comicity' or humor, the speaker restricts the language used in order to produce the intentional representation of the object of parody, flaunts that representation and restricts criticism; in short, it integrates or manipulates these three types of acts with the aim of creating the comic act.

In this context, they propose the following model for verbal parody:

${ }^{8}$ Levinson (2000) suggests a maxim for the speaker and a corollary for the interlocutor as pragmatic principles. Quantity, Q-principle (Levinson, 2000: 76):

Speaker's maxim: Do not provide information which is weaker than the knowledge of the world that you own; more precisely, select the strongest element in the paradigm.

Interlocutor's corollary: The information offered by the speaker is the strongest one that he can provide.

Manner, M-principle (Levinson, 2000: 136-137):

Speaker's maxim: Indicate a normal situation by means of non-marked expressions.

Interlocutor's corollary: A marked expression describes a non-stereotypical situation.

Informativity (I-principle) (Levinson, 2000: 114):

Speaker's maxim: Provide minimum information which suffices to achieve your communicative aims.

Interlocutor's corollary: Elaborate on the content of the speaker's utterance until the specific interpretation is found.

With regard to the inferential processes triggered by humor, they mainly occur as an infringement of the Informativity principle proposed by Levinson (2000). Referents in humor multiply by means of indicators such as polysemy, homonymy, ambiguity, synonymy or the use of pseudocomprehensive elements. The other two pragmatic principles, the Manner principle and the Quantity principle, are equally infringed in humor, although they depend on the humorous context facilitating the infringement of the Informativity principle. For further information about the way in which these principles are infringed in irony and humor, see Ruiz Gurillo (2010). 


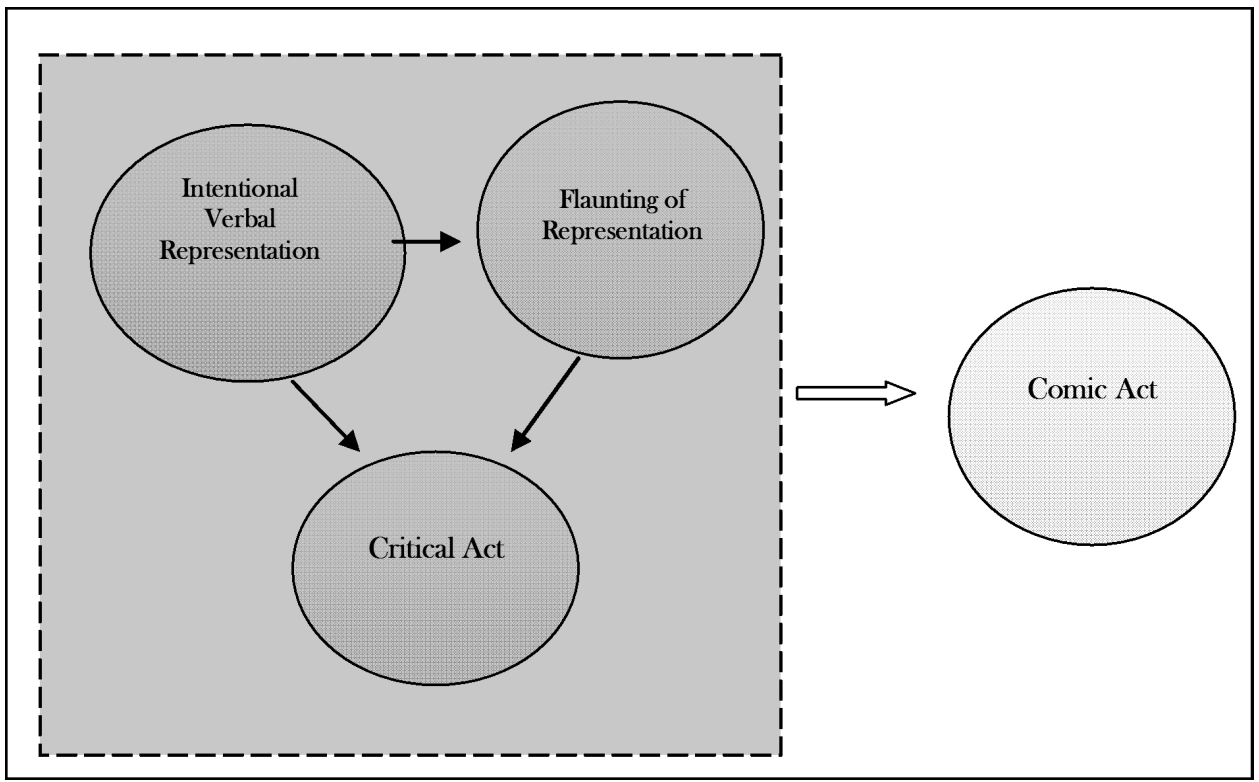

Figure 3: A model of verbal parody according to Rossen-Knill \& Henry (1997:736)

Therefore, parody is based on intertextuality or, to put in another way, it dialectically opposes an original text to the text built as parody. It has an ideological component and, in the case of television, it implies a frivolous use of information. For this reason, it is important to consider which language is used, who is the addressee of the mockery, which procedures are used to flaunt that parody, who is criticized and how and, finally, how 'comicity' or humor is produced.

\section{The evaluative aspects of parody}

Rossen-Knill \& Henry (1997) explain that the comic act of parody is achieved, amongst other aspects, through the selection of a linguistic form and a target. In our view, these linguistic elements represent evaluative elements at the service of mockery, the foundation of parody and, consequently, of humor. According to a widely accepted concept of evaluation (Labov \& Waletzky, 1967), evaluation is a part of the narration. Therefore, stories would have an initial situation, a climax, an evaluation and a resolu- 
tion. Nevertheless, some of these authors (Laforest, 1996; Silva Corvalán, $1987^{9}$ ) point out that evaluation is not only a structural part of the account but also a function or procedure which helps maintain the interest throughout the story. Therefore, instead of being understood as a structure, evaluation is a discursive function of the narration, more specifically, a linguistic expression of the opinion transmitted by the speaker/writer (Bednarek, 2009). Its main role consists in persuading the addressee about a system of values or transmitting social or political criticism, amongst others, to that addressee.

Evaluation has been analyzed in its relationship with irony (Kotthoff, 2003; Partington, 2007 and 2011). For the latter author, evaluation is present in practically every form of linguistic communication, where it becomes a persuasion tool which helps the speaker/writer transmit a certain way of thinking to the audience (Partington, 2011: 1787). It can consequently impose a system of values in an explicit or implicit way. In this respect, irony markers are a tool for social control or criticism and, consequently, for persuasion. Their role is relevant in argumentative texts such as those found in newspapers or political debates (Partington, 2007).

Different evaluation methods are utilized in the case of parody. According to Rossen-Knill \& Henry (1997), parody integrates an intentional verbal representation comprised by a specific linguistic form and a target of the mockery. Following the GTVH proposal presented in $₫ 2$, the target becomes one of the main knowledge resources. A variety of linguistic elements are used to achieve the mockery and, consequently, to persuade the audience about a state of affairs. Both the linguistic markers and the linguistic indicators represent evaluative expressions at the service of persuasion and criticism, more precisely of the comic act and the critical act. In this respect, suprasegmental markers (pauses, rising and suspended tonemes, intensity) or morphological ones (discourse markers) are used. A variety of humorous indicators are present as well, among which stand out polysemy, ambiguity or phraseology. Therefore, these linguistic and extralinguistic elements become evaluative expressions contributing to the comic act of parody.

Figure 4 offers a summary of the evaluation aspects related to parody:

\footnotetext{
${ }^{9}$ In her opinion, the parts of the oral narration are the summary, despite not being very frequent in these expressions, the orientation, the complication of the action, the evaluation, the result or resolution, and the coda (Silva Corvalán, 1987: 267).
} 


\begin{tabular}{|l|l|}
\hline $\begin{array}{l}\text { Evaluation is a part of the narration } \\
\text { Presentation }\end{array}$ & Evaluation is a persuasion procedure (comic act) \\
$\begin{array}{ll}\text { Exposition-illustration } & \text {-Kinesic elements: smile, gestures of support } \\
\text { Evaluation } & \text {-Paralinguistic elements: pauses, intensity } \\
\text { Coda } & \text {-Linguistic elements: evidentials, discourse } \\
& \text { markers, phraseology, polysemy } \\
\end{array}$ \\
\end{tabular}

Figure 4: Evaluation in parody

\section{A type of parody: the sketch on TV}

The previous theoretical foundations developed in $₫ 2,3$ and 4 will now be the reference for our analysis of a sketch taken from a television show, Saturday Night Live, broadcast by the channel Cuatro in Spain - a program based on the American model with the same name- . A sketch is a comic scene which lasts between 5 and 10 minutes, usually performed in a theatre or on television. The sketches constructed for the program, which is broadcast live, parody news or everyday situations before a real audience in the recording room. The sketch in question is supported on the structure of infomercials for medicines and uses sociocultural data such as the economic crisis and the increase in the number of unemployed people in Spain. More precisely, the actor José Luis Gil, better known by his roles in TV series such as Aqui no hay quien viva [No one can live here] and La que se avecina [What is drawing near] plays here Dr. Lilly and shows us the two new medicines for the crisis, Melasuda [Couldntgivedamn] and Keosden [Fukyall]. Melasuda [Couldntgiveadamn] is the first conscience-anesthetizing pill, recommended for power consciences such as Bush, Zapatero or Bill Gates:

(1)

Dr. Lilly: hola/hola// soy el doctor Lilly de los laboratorios Hoffman y estoy aquí para PREsentarles una nueva GAMA de medicamentos para sobrevivir a estos tiempos tan difíciles// por fin se legaliza en nuestro país la primera píldora anestesiadora de conciencias

[Dr. Lilly: hello/hello// I'm doctor Lilly from the Hoffman laboratories and I'm here to PREsent (before) you a new RANGE of medicines to survive these terribly difficult times// the first conscience- anesthetizing pill has finally been legalized in our country] 
People who have to face real problems such as unemployment, crisis, mortgages or love-life situations are advised to take Keosden [Fukyall] and Keosden forte [Fukyall forte]:

(2)

Dr. Lilly: (...) Keosden está especialmente indicado en casos de hipotecas abusivas $\uparrow /$ situaciones laborales precariaas $\uparrow$ y situaciones sentimentales rutinarias// que sus problemas son demasiado gordos $\uparrow$ ¡NO SE PREOCUPE! también tenemos Keosden Forte

[Dr. Lilly: (...) Fukyall is especially recommended in cases of outrageous mortgages $\uparrow /$ precarioous work situations $\uparrow$ and routine love-life situations// if your problems are too serious $\uparrow$ DO NOT WORRY! we also have Fukyall Forte]

The postulates established by Rossen-Knill \& Henry (1997), and the analysis of markers and indicators as evaluation procedures, indicators and markers will be analyzed according to the GTVH proposal. Let us start with the strategies utilized in this sketch. For instance, the language adopts a formal tone and has been carefully planned. The interpersonal goal is to persuade the audience to buy the advertised medicines and, therefore, the text is essentially expository-argumentative. That is the reason why Dr. Lilly explains the qualities of the medicines Melasuda [Couldntgiveadamn] and Keosden [Fukyall] and backs those qualities specifying their composition:

(3)

Dr. Lilly: Melasuda $\uparrow$ anestesia sus reparos morales hasta difuminarlos del todo/Melasuda $\uparrow$ lleva extracto de melasudina $\downarrow$ valeriana $\downarrow$ hierba de relax del Tibet y diez miligramos de opio

[Dr. Lilly: Couldntgiveadamn $\uparrow$ anesthetizes your moral reservations until they bcome completely blurred/Couldntgiveadamn $\uparrow$ contains extract of couldntgiveadamnine $\downarrow$ valerian $\downarrow$ relax herb from Tibet and ten milligrams of opium]

(4)

Dr. Lilly: KEOSDEN/ Keosden lleva una composición similar a Melasuda pero con un POQUITO de ácido lisérgico que cambia su percepción de la realidad para que usted sea capaz de mandarlo todo a la mierda

[Dr. Lilly: FUCKYOU/ Fukyall has a composition similar to (that of) Couldntgiveadamn but with a LITTLE BIT of lysergic acid which changes your perception of reality for you to decide that everything can go to hell]

Real testimonies are used to illustrate the effectiveness of these false medicines. The contraindications given by the voice offscreen equally appear on the screen with white letters on a blue background (as it happens in real medicine commercials): 
(5)

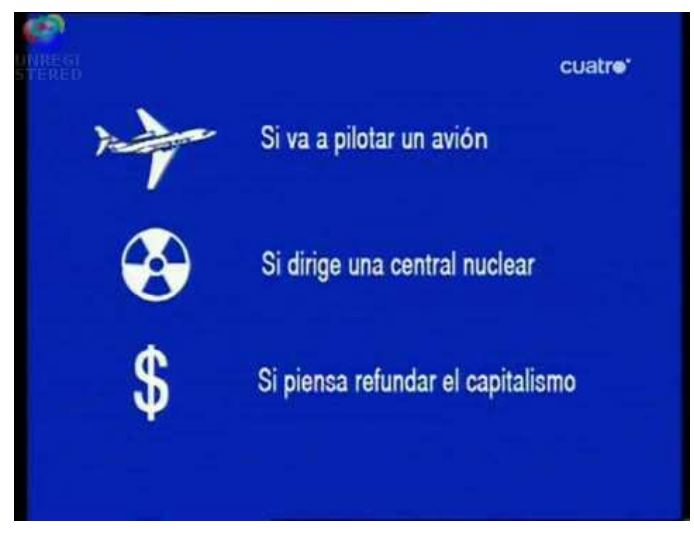

[If you are going to fly a plane/If you run a nuclear power station/If you plan to refound capitalism]

The false medicines are presented in containers resembling those of real medicines, with black letters printed on a white or green background, as is the case with Keosden [Fukyall]:

(6)

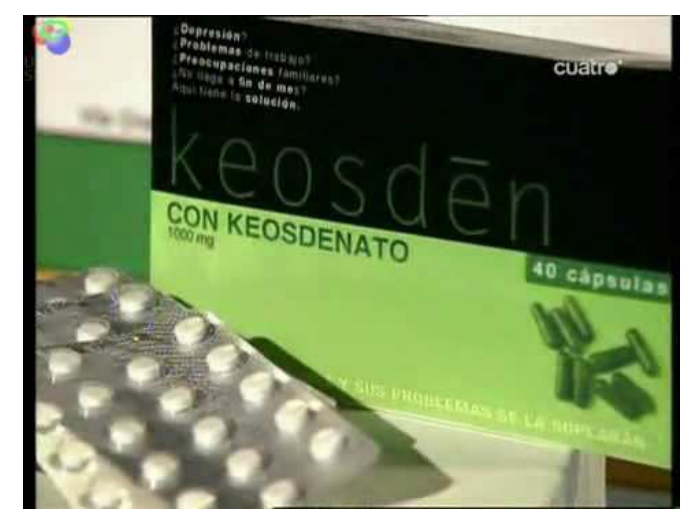

Furthermore, their properties are supposedly backed by their 'serious' composition [e.g. 'con keosdenato' = with Fukyallate] as it happens with the aforementioned lysergic acid, commonly known as LSD, a hallucinogenic compound. In other words, the infomercial about the medicines Melasuda [Couldntgiveadamn] and Keosden [Fukyall] has the structure and the basic parts of a serious infomercial about any medicine. The narrative strategy of humor is built upon these foundations. In this case, there is a presen- 
tation of the problem, an exposition of events, an evaluation and a coda, which are specified in Figure 5 below:

\begin{tabular}{|c|c|}
\hline Presentation & $\begin{array}{l}\text { por fin se legaliza en nuestro país la primera píldora anestesiadora de conciencias } \\
\text { [the first conscience-anesthetizing pill has finally been legalized in our country] }\end{array}$ \\
\hline Exposition-illustration & $\begin{array}{l}\text { Melasuda } \uparrow \text { lleva extracto de melasudina } \downarrow \text { valeriana } \downarrow \text { hierba de relax del Tibet y } \\
\text { diez miligramos de opio } \\
\text { [Couldntgiveadamn } \uparrow \text { contains extract of couldntgiveadamnine } \downarrow \text { valerian } \downarrow \text { relax } \\
\text { herb from Tibet and ten milligrams of opium] } \\
\text { escuchemos ahora TESTIMONIOS } \\
\text { [Let's listen to some TESTIMONIES now }\end{array}$ \\
\hline Evaluation & $\begin{array}{l}\text { porque en este mundo lo que mata ES LA PREOCUPACIÓN } \\
\text { [because what kills in this world is WORRY] }\end{array}$ \\
\hline Coda & $\begin{array}{l}\text { si lo compran Melasuda// y si no lo compran Keosden// forte } \\
\text { [if you buy it Couldntgiveadamn// and if you don't buy it Fukyall// fortel }\end{array}$ \\
\hline
\end{tabular}

Figure 5: Parts of the sketch as a narrative-expository text

Nevertheless, despite the structural room reserved for the evaluation of the story, humor markers and indicators act as procedures in the construction of parody and social criticism. It is obvious that the medicines Melasuda [Couldntgiveadamn] and Keosden [Fukyall] comprise - supposedly 'serious'- active principles such as melasudina [couldntgiveadamnine] and keosdenato [fukyallate], built through phraseological derivation, which emulate the active principles of real medicines.

Therefore, with regard to the target, it could be said that the sketch denounces the politicians, economists and entrepreneurs who have led their fellow citizens to a situation of crisis. Seeking to flaunt this specific language and the people to whom the mockery is addressed, the actors build an echo of an initial situation, that of the infomercial about a medicine, in which are inserted other echoes such as the action of politicians and entrepreneurs. The intentional verbal representation consequently uses evaluative elements, among which stand out markers and indicators.

The Intentional Verbal Representation described by Rossen-Knill \& Henry (1997) entails the infringement of pragmatic principles; according to Levinson (2000) and Rodríguez-Rosique (2009) the quality prerequisite is firstly infringed through the construction of an obviously false context which evokes the original one. Certain markers contribute to the generation of this humorous environment, such as kinesic elements (gestures of support or assent) or laughter. We can see the importance of gestures when it comes to present the medicine in (7): 
(7)

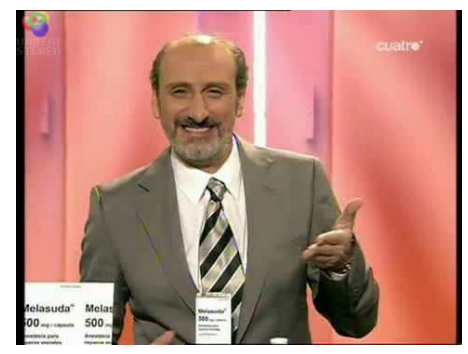

In (8), Dr. Lilly reinforces the testimony provided by the film director Alex Raminovich with his facial expression:

(8)

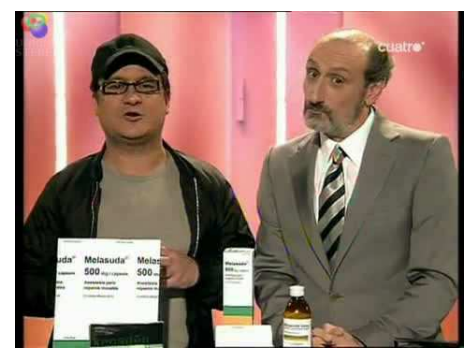

Also suprasegmental elements such as pauses, tonemes or intensity in the voice contribute to the parody. Thus, the intensity used by Dr. Lilly when uttering certain words in (9) helps understand the benefits of this medicine. In turn, Cándido Zamora shows his anger by means of intensity:

(9)

Dr. Lilly: que no hombre que no/ se trata de $\rightarrow$ / KEOSDEN/ Keosden lleva una composición similar a Melasuda pero con un POQUITO de ácido lisérgico que cambia su percepción de la realidad para que usted sea capaz de mandarlo todo a la mierda Zamora: ¡PUES HALA! ¡A LA MIEERDA! ¡KEOSDEN!

[Dr. Lilly: no way/ man/ no way/ it is $\rightarrow$ / FUKYALL/ Fukyall has a composition similar to (that of) Couldntgiveadamn but with a LITTLE BIT of lysergic acid which changes your perception of reality for you to decide that everything can go to hell

Zamora: COME ON THEN! TO HEELL! FUKYALL!]

In that context, the medicines Melasuda [Couldntgiveadamn] and Keosden [Fukyall] show their effectiveness as conscience anesthetizers, a strange indication for a medicine: 
(10)

Dr. Lilly: para todos los demás $\uparrow /$ Melasuda $\uparrow /$ o Keosden

[Dr. Lilly: for all the others $\uparrow /$ Couldntgiveadamn $\uparrow /$ or Fukyall]

The Informativity principle is infringed too, since the multiplication of referents is present at all times; in fact, the names of these medicines refer to two highly common rude formulas used in spontaneous, everyday speech which show lack of interest in something: ique os den! [Fuck y'all!] and ¡me la suda! [I couldn't give a damn!] (Alvarado, 2010). The fact that they are sometimes used as formulas and sometimes as the names of the advertised medicines causes a continuous infringement of the Informativity principle. This is additionally reinforced by the violation of the Manner principle, as these everyday formulas are marked expressions:

Dr. Lilly: para todos los demás $\uparrow /$ Melasuda $\uparrow /$ o Keosden/ porque en este mundo lo que mata ES LA PREOCUPACIÓN/ cómprelo en su farmacia más cercana/ o no// a mí me la suda

Público: (RISAS)

Dr. Lilly: si lo compran Melasuda// y si no lo compran Keosden// forte

[Dr. Lilly: for all the others $\uparrow /$ Couldntgiveadamn $\uparrow /$ or Fukyall/ because what kills in this world IS WORRY/ buy it at the nearest drugstore/ or not// I couldn't give a damn

Audience: (LAUGHTER)

Dr. Lilly: if you buy it Couldntgiveadamn// and if you don't buy it Fukyall// forte]

The infringement of the Manner principle also becomes visible in the constant use of the specialized language that is typical of medicine:

Dr. Lilly: Keosden está especialmente indicado en casos de hipotecas abusivas $\uparrow /$ situaciones laborales precariaas $\uparrow$ y situaciones sentimentales rutinarias

[Dr. Lilly: Fukyall is especially recommended in cases of outrageous mortgages $\uparrow$ / precarioous work situations $\uparrow$ and routine love-life situations

With specific regard to the infringement of the Informativity Principle, certain indicators outstandingly act as evaluative procedures. First, the generation of pseudocomprehensive elements, that is, the creation of a class that exhausts itself in its integrating elements but which can only be understood in a humorous way. In other words, an echo of the precautions or side effects that real medicines can cause is used to make explicit the 'humorous' situations under which the medicine must be avoided: 
(13)

Voz en off: evite tomar Melasuda o Keosden si va a pilotar un avión $\downarrow$ si dirige una central nuclear $\downarrow$ o si piensa refundar el capitalismo

[Offscreen voice: avoid taking Couldntgiveadamn or Fukyall if you are going to fly a plane $\downarrow$ if you run a nuclear power station $\downarrow$ or if you plan to refound capitalism]

However, the evaluative indicator most often used throughout the text is the presence of ambiguity, which clearly infringes the Informativity principle. We can see in (14) — the punch line of the humorous text - that the verb matar [kill] is used both in its proper sense and figuratively:

Dr. Lilly: para todos los demás $\uparrow /$ Melasuda $\uparrow /$ o Keosden/ porque en este mundo lo que mata ES LA PREOCUPACIÓN

[Dr. Lilly: for all the others $\uparrow /$ Couldntgiveadamn $\uparrow /$ or Fukyall/ because what kills in this world IS WORRY]

The flaunting of the intentional representation of parody is reinforced by the laughter among the audience, which responds in this way to the jokes included in the sketch.

On the other hand, the critical act implies a joke about the parodied situations, the behavior of politicians or entrepreneurs. The sketch makes available a remedy against its conscience-related illnesses to any suffering mind - whether it is the mind of a relevant figure or that of an average citizen-. For this reason, the criticism is addressed both to the important figures who rule us and to the whole population ruled by them. These medicines have been created for them all. Furthermore, there is a veiled attack against television infomercials, which sell any type of medicine or remedy, even those with dubious effectiveness.

Within the framework of this model, the flaunting of the representation permits this sketch to echo a serious text, infomercials about medicines in this case, using this echoing procedure to manage a veiled criticism both about this type of information and about the actions of politicians and entrepreneurs in relation to the crisis. The sketch fulfills its humorous objectives precisely because the utilization that is made of language turns out to be an example of metapragmatic awareness (Verschueren, 1999 and 2009): the scriptwriters or comedians observe the range of variables among the possible choices; negotiate those choices in context; and, finally, adapt to the possible options which permit them to achieve their basic goal, to amuse the audience. Therefore, the linguistic and paralinguistic choices that we find in this sketch are markers and indicators of humor and facilitate the inference process carried out by the addressees, a process in which the serious text echoed by this humorous genre acts as the framework. 
In short, the sketch turns out to be funny because it is well managed: the actors follow the previously established script for parody. They reinforce their performances with kinesic elements, such as smiles or gestures of support, which gradually appear on the screen; also with paralinguistic elements that highlight the linguistic aspects, such as the utilization of pauses before introducing the main topics and the use of intensity or prosody. In fact, a large part of the 'comicity' or humor stems from the exaggerated, even ridiculous use of these paralinguistic elements as verbal support, as explicit expressions of evaluation. Likewise, the intentional use of language (the utilization of highly common rude expressions as commercial names of medicines, the use of those marked expressions) is restricted to achieve the comic effect. Summing up, the sketch echoes serious infomercials but includes a veiled criticism of them, simultaneously questioning the behavior of politicians and other relevant figures.

\section{Conclusions}

This article shows one way in which a specific form of humor, parody —and, more precisely a type of it, television parody - can be analyzed. The situation where these humorous texts occur, along with their television-related function, served as a reference framework for our analysis. Furthermore, considering it as a satirical discourse permits to establish a connection with this broader form of humorous discourse. In fact, the consideration of verbal parody as a speech act —following Rossen-Knill \& Henry (1997) - provided with an explanation that we have integrated into the six knowledge resources collected in the GTVH. It is consequently formed by an intentional verbal representation of the parody target (both the linguistic form and the target); there is a flaunting of that representation; and a critical act takes place too. These three aspects are restricted in the comic act, the essence of verbal parody. Such foundations were the basis for our analysis of a television sketch which, adopting the format of an infomercial about 'serious' medicines, advertises two conscience-anesthetizing medicines, Melasuda [Couldntgiveadamn] and Keosden [Fukyall]. We have studied evaluation as a structural part of the narration, but also as the procedure which, thanks to markers such as prosody, intensity and laughter, and to indicators such as phraseology, pseudocomprehensive elements, polysemy or ambiguity, permits to persuade the audience about a state of affairs and, more precisely, to take a stance before the outrageous behavior of politicians and entrepreneurs.

The GTVH model described here and illustrated for parody, specifically for a television sketch about the medicines Melasuda [Couldntgiveadamn] and Keosden [Fukyall] may be exported to other television parodies, such as the television programs based on 
informative parody (El intermedio [The intermission]), where the target appears as the most important knowledge resource. However, the development of narrative strategies by means of aspects related to the genre, register and type of text used may contribute to the explanation of other genres like the humorous monologue (Ruiz-Gurillo, 2012).

Figure 6 summarizes the most outstanding aspects which were taken into account for the analysis of evaluation in parody:

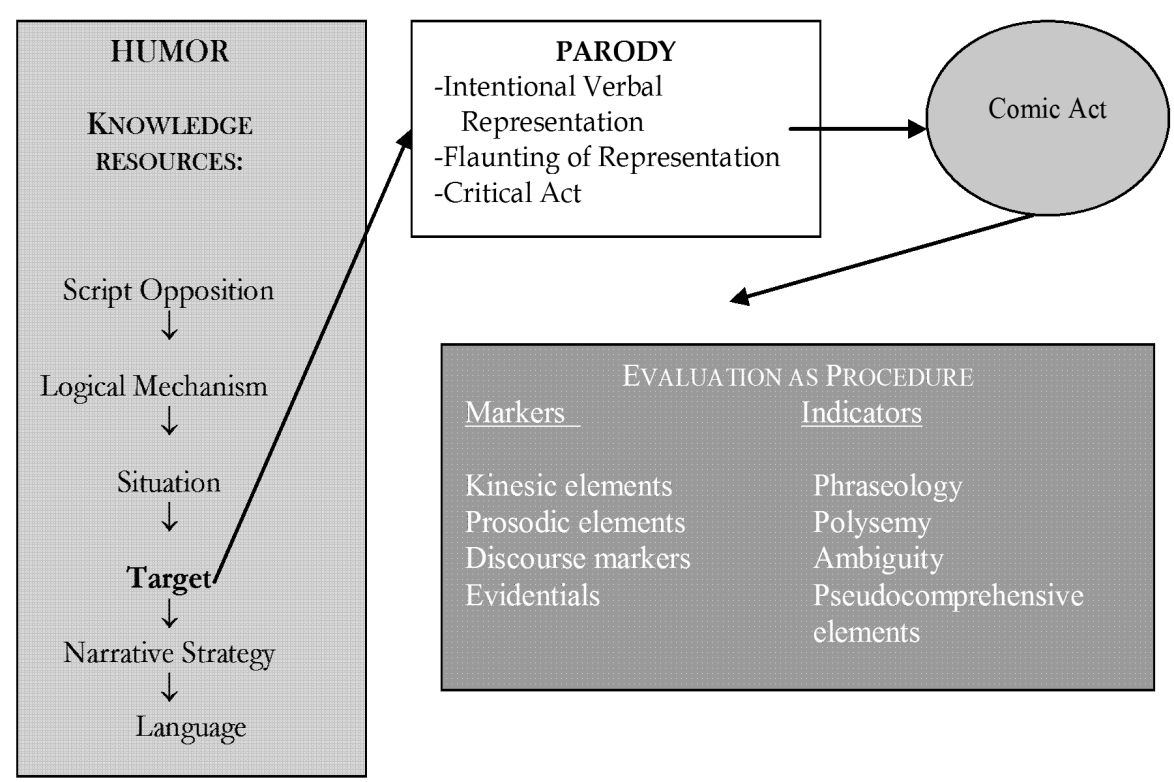

EVALUATION AS STRUCTURE:

Presentation, Exposition-illustration, evaluation and coda

Figure 6: Evaluation in parody

Recibido: 22-IX-2012

Aceptado: 14-IV-2013

\section{Bibliographic references}

Adam, J-M (2001): Les textes: types et prototypes. Récit, description, argumentation, explication et dialogue (Des réponses originales à l'analyse des textes: la reconnaisance des séquences). Paris, Nathan.

Alvarado, Ma B. (2010): Las fórmulas rutinarias del español. Teoría y aplicaciones. 
Frankfurt, Peter Lang.

Attardo, S. \& V. Raskin (1991): "Script theory revis(it)ed: Joke similarity and joke representation model”, Humor, 4 (3-4), págs. 293-347.

Attardo, S., Ch. F. Hempelmann \& S. Di Maio (2002): "Script oppositions and logical mechanisms: Modelling incongruities and their resolutions", Humor, 15 (1), págs. 3-46.

Attardo, S. (1994): Linguistic Theories of Humor. Berlin, Mouton de Gruyter.

Attardo, S. (1997): "Locutionary and perlocutionary cooperation: the perlocutionary cooperative principle”, Journal of Pragmatics, 27, págs. 753-779.

Attardo, S. (1999): "The place of cooperation in cognition", European Conference of Cognitive Science (ECCS'99). Siena, Italy, October. 27-30, págs. 459-464.

Attardo, S. (2001a): Humorous Texts: A Semantic and Pragmatic Analysis. Berlin, Mouton de Gruyter.

Attardo, S. (2001b): "Humor and Irony in Interaction: From Mode Adoption to Failure of Detection". In Anolli, L., R. Ciceri \& G. Riva (eds.): Say not Say: New perspectives on miscommunication. Amsterdam: IOS Press, págs. 165-185.

Attardo, S. (2003a): "Multimodal markers of irony and sarcasm”, Humor, 16 (2), págs. 243-260.

Attardo, S. (2003b): "Introduction: the Pragmatics of humor", Journal of Pragmatics, 35, págs. 1287-1294.

Attardo, S. (2004): “Preface”, Humor, 17 (4), págs. 351-352.

Attardo, S. (2006): “Cognitive linguistics and humor”, Humor, 19 (3), págs. 341-362.

Attardo, S. (2008): "A primer for the linguistics of humor". In Raskin, V. (ed.): The Primer of Humor Research. Berlin, Mouton de Gruyter, págs. 101-155.

Attardo, S., J. Eisterhold, J. Hay \& I. Poggi (2003): "Multimodal markers of irony and sarcasm", Humor, 16 (2), págs. 243-260.

Bednarek, M. (2009): "Dimensions of evaluation. Cognitive and linguistic perspectives", Pragmatics \& Cognition, 17:1, págs. 146-175.

Bordería, E. et alii (2010): La risa periodística. Teoría, metodología e investigación en comunicación satírica. Valencia, Tirant lo Blanch.

Brône, G. (2008): "Hyper- and misunderstanding in interactional humor", Journal of Pragmatics, 40, págs. 2027-2061.

Brône, G. \& K. Feyaerts (2003): "The cognitive linguistics of incongruity resolution: Marked reference-point structures in humor", Paper delivered at the $8^{\text {th }}$ International Cognitive Linguistics Conference. (La Rioja (Spain), 20-25 June 2003).

Brône, G., K. Feyaerts \& T. Veale (eds.). (2006): Cognitive Linguistics meets Humor Research: Current trends and new developments. Berlin, Mouton de Gruyter. 
Brône, G., K. Feyaerts \& T. Veale (2006): "Introduction: Cognitive linguistics approaches to humor”, Humor, 19 (3), págs. 203-228.

Charaudeau, P. (2006): “Des catégories pour l'humour?", Question de communication, 10, págs. 19-41.

Curcó, C. (1995): "Some observations on the pragmatics of humorous interpretations. A relevance-theoretic approach", UCL Working Papers in Linguistics, págs. 727-47.

Curcó, C. (1996): “The implicit expression of attitudes, mutual manifestness and verbal humour", UCL Working Papers in Linguistics 8, págs. 89-99.

Curcó, C. (2000): "Irony: Negation, echo and metarepresentation", Lingua, 110, págs. 257-280.

Ermida, I. (2008): The language of comic Narratives. Humor Construction in Short Stories. Berlin, Mouton de Gruyter.

Feyaerts, K. (2006): "Towards a Dynamic Account of Phraseological Meaning: Creative Variation in Headlines and Conversational Humour", International Journal of English Studies, vol. 6 (1) (University of Murcia), págs. 57-84.

Hunston, S. \& G. Thompson (eds) (2000): Evaluation in Text. Authorial Stance and the Construction of Discourse. Oxford, Oxford University Press.

Kotthoff, H. (2007): "Oral genres of humor: On the dialectic of genre knowledge and creative authoring”, Pragmatics, 17, 2, págs. 263-296.

Labov, W. J. Waletzky (1967): "Narrative analysis: oral versions of personal experience". In Helms, J. (ed.): Essays on the verbal and visual arts. Seatle, University of Washington Press , págs. 12-44.

Laforest, M. (1996): "De la manière d'écouter les histoires, la part du narrataire". In M. Laforest (ed.): Autour de la narration. Québec, Nuit Blanche, págs. 73-95.

Lefort, B. (1999): "Le discours comique et sa réception: le cas des histoires drôles". In Rosier, L. \& J-M. Defays (eds.): Approches du discours comique. Mardaga, págs. 113132.

Levinson, S. C. (2000): Presumptive Meanings. The Theory of Generalized Conversational Implicature. Cambridge, Massachusetts.

Méndez García de Paredes, E. (2004): "Humor y televisión en España”, L’humour hispanique Lyon, Université de Lyon II, págs. 147-190.

Partington, A. (2007): "Irony and reversal of evaluation", Journal of Pragmatics, 39, 9, págs. 1547-1569.

Partington, A. (2011): "Phrasal irony: Its form, function and exploitation", Journal of Pragmatics, 43, págs. 1786-1800.

Pueo, J. C. (2002): Los reflejos en juego. Una teoría de la parodia. Valencia, Tirant lo Blanch. 
Raskin, V. (1985): Semantic Mechanisms of Humor. Reidel, Dordrecht.

Raskin, V. (1998): “Humor”. In Mey, J. (ed.): Concise Encyclopedia of Pragmatics. Amsterdam, Elsevier, págs. 354-359.

Raskin, V. (2004): “Afterword”, Humor, 17-4, págs. 429-436.

Raskin, V. (2008): "Theory of humor and practice of humor research: Editor's notes and thoughts". In Raskin, Victor. (ed.): The Primer of Humor Research. Berlin, Mouton de Gruyter, págs. 1-16.

Raskin, V. (ed.) (2008): The Primer of Humor Research. Berlin, Mouton de Gruyter.

Rodríguez-Rosique, S. (2009): "Una propuesta neogriceana". En Ruiz-Gurillo, L. y X. A. Padilla García (eds.), págs. 109-132.

Rossen-Knill, D. F. \& R. Henry (1997): “The pragmatics of verbal parody", Journal of Pragmatics, 27, págs. 719-752.

Ruiz-Gurillo, L. y X. A. Padilla García. (eds.) (2009): Dime cómo ironizas y te diré quién eres. Una aproximación pragmática a la ironía. Frankfurt, Peter Lang.

Ruiz-Gurillo, L. (2006): Hechos pragmáticos del español. Alicante, Universidad de Alicante.

Ruiz-Gurillo, L. (2010): "Para una aproximación neogriceana a la ironía en español", Revista Española de Lingüística, 40/2, págs. 95-124.

Ruiz-Gurillo, L. (2012): La lingüistica del humor In español. Madrid, Arco/Libros.

Ruiz-Gurillo, L. (2013): “Narrative strategies in Buenafuente's humorous monologues”. In Ruiz-Gurillo, L. \& M. Belen Alvarado-Ortega (eds.), págs. 107-140.

Ruiz-Gurillo, L. \& M. Belen Alvarado-Ortega (eds.) (2013): Irony and Humor: From Pragmatics to Discourse. Amsterdam, John Benjamins.

Schoentjes, P. (2003): La poética de la ironía. Madrid, Cátedra.

Silva Corvalán, C. (1987): "La narración oral española, estructura \& significado. En Bernárdez, Enrique. (Comp.): Lingüística del texto. Madrid, Arco-Libros, págs. 265292.

Simpson, P. (2003): On the Discourse of Satire. Amsterdam, John Benjamins.

Sperber, D. y D. Wilson (1994): La relevancia, comunicación y procesos cognitivos. Madrid, Visor.

Sperber, D. (ed.) (2000): Metarepresentations. A multidisciplinary perspective. Oxford, University Press.

Timofeeva, L. (2008): Acerca de los aspectos traductológicos de la fraseología española. En: http://rua.ua.es/dspace/handle/10045/7707.

Veale, T., K. Feyaerts \& G. Brône (2006): "The cognitive mechanisms of adversarial humor", Humor, 19-3, págs. 305-338.

Verschueren, J. (1999): Understanding Pragmatics. London, Arnold. 
Verschueren, J. (2009): “The pragmatics perspective”. In Verschueren, J. \& J-O Östman (eds.) (2009): Key Notions for Pragmatics. Handbook of Pragmatics Highlights, 1. Amsterdam, John Benjamins, págs. 1-27.

Wilson, D. \& D. Sperber (2004): "La Teoría de la Relevancia", Revista de Investigación Lingüística, vol. VII, págs. 233-282. [Translation of Wilson, D. \& D. Sperber (2004): "The Theory of Relevance". In Horn, L. \& G. Ward (eds.) The Handbook of Pragmatics. Blackwell, Oxford, págs. 607-632].

Wilson, D. (2000): "Metarepresentation in linguistic communication." In Sperber, D. (ed.), págs. 411-448.

Wilson, D. (2006): “The pragmatics of verbal irony: Echo or pretence?", Lingua, 116, págs. 1722-1743.

Yus, F. (1995-1996): "La teoría de la relevancia y la estrategia humorística de la incongruencia-resolución”, Pragmalingüística 3-4, págs. 497-508.

Yus, F. (2002): "Stand-up comedy and cultural spread: The case of sex roles", Babel AFIAL, 10, págs. 245-292.

Yus, F. (2003): "Humor and the search for relevance", Journal of Pragmatics, 35, págs. 1295-1331.

Yus, F. (2004): "Pragmatics of humorous strategies in El club de la comedia." In Márquez-Reiter, R. \& M. E. Placencia (eds): Current Trends in the Pragmatics of Spanish. Amsterdam, John Benjamins, págs. 320-344.

Yus, F. (2009): "Saturación contextual en la comprensión de la ironía". En Ruiz-Gurillo, L. y X. A. Padilla García (eds.), págs. 309-331. 